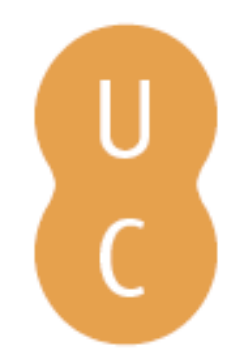

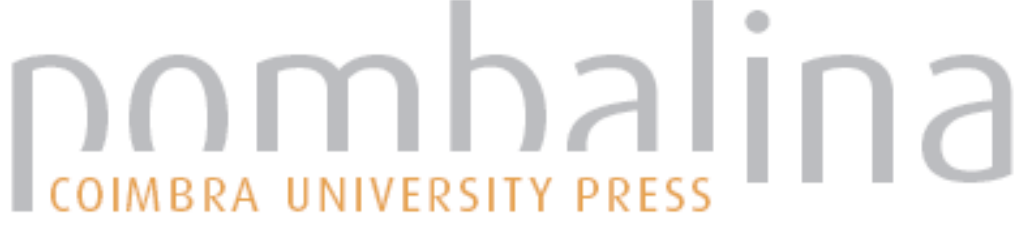

\section{Labirinto, escrita e eternidade em Aparição de Vergílio Ferreira}

Autor(es): $\quad$ Cardoso, Margarida

Publicado por: Imprensa da Universidade de Coimbra

URL

persistente: URI:http://hdl.handle.net/10316.2/38692

DOI: $\quad$ DOI:http://dx.doi.org/10.14195/978-989-26-1164-8_15

Accessed : $\quad$ 26-Apr-2023 10:44:42

A navegação consulta e descarregamento dos títulos inseridos nas Bibliotecas Digitais UC Digitalis, UC Pombalina e UC Impactum, pressupõem a aceitação plena e sem reservas dos Termos e Condições de Uso destas Bibliotecas Digitais, disponíveis em https://digitalis.uc.pt/pt-pt/termos.

Conforme exposto nos referidos Termos e Condições de Uso, o descarregamento de títulos de acesso restrito requer uma licença válida de autorização devendo o utilizador aceder ao(s) documento(s) a partir de um endereço de IP da instituição detentora da supramencionada licença.

Ao utilizador é apenas permitido o descarregamento para uso pessoal, pelo que o emprego do(s) título(s) descarregado(s) para outro fim, designadamente comercial, carece de autorização do respetivo autor ou editor da obra.

Na medida em que todas as obras da UC Digitalis se encontram protegidas pelo Código do Direito de Autor e Direitos Conexos e demais legislação aplicável, toda a cópia, parcial ou total, deste documento, nos casos em que é legalmente admitida, deverá conter ou fazer-se acompanhar por este aviso.

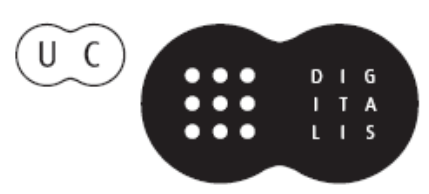


Margarida Cardoso

Escola Secundária de Pombal

\section{LABIRINTO, ESCRITA E ETERNIDADE EM APARIÇÃO DE VERGÍLIO FERREIRA}

"Habita-me o espaço e a desolação"1. Nem mesmo os mais fiéis leitores de Vergílio Ferreira, habituados à originalidade sintática do seu discurso, ficarão indiferentes a esta afirmação que o protagonista de Aparição regista pouco após a sua chegada a Évora, cidade labiríntica. O emprego pronominal de "habitar" e a estranha atribuição a esse verbo de um sujeito pouco usual neste contexto ("espaço"), ao qual se apõe um substantivo abstrato ("desolação"), deixam supor que personagem, espaço, desolação e a própria escrita constituem um todo indivisível. Não é por acaso que, em momentos de angústia e "cansaço profundo" (p. 14), de perturbação e "raiva milenária" (p. 87), de solidão e "cólera sangrenta" (p. 169), Alberto Soares se refugia no cenário genesíaco da montanha para se encontrar consigo e com a escrita ou, ao invés, se compraz a percorrer "ruas silenciosas, emaranhadas como uma alucinação" (p. 73), como a tentar fugir de si próprio ${ }^{2}$. Num caso como noutro, no fulgor da aparição fantástica do ser ou no repercutir das vozes do tempo que chamam dos quatro cantos do espaço, parece mergulhar numa dimensão temporal que roça o eterno.

\footnotetext{
1 Vergílio Ferreira, Aparição, Venda Nova, Bertrand Editora, 2000, 50a ed., p. 24. Todas as citações do romance se referem a esta edição.

2 Id., ibidem, p. 87: "Assim me agradava percorrer as ruas como se fugisse de mim". Na verdade, segundo o Dictionnaire des Symboles de Jean Chevalier e Alain Gheerbrant (Paris, Laffont, 1982), "Le labyrinthe conduit [...] à l'intérieur de soi-même, vers une sorte de sanctuaire intérieur et caché, dans lequel siège le plus mystérieux de la personne humaine" (p. 555). O motivo do labirinto é algo recorrente na obra de Vergílio Ferreira. Por exemplo, a frase introdutória do primeiro e do último capítulos de Signo Sinal é: "Vou à deriva pelo labirinto das ruas" (Círculo de Leitores, 1978, pp. 7 e 233).
} 
Preso num dédalo de vielas e de inquietações, procura a paz no silêncio dos espaços infinitos, na arte que lhe revela a evidência, na escrita que permite a descoberta do seu ser e torna "visível o mistério das coisas"3. Na imensidão do mar, encontra o reconforto, já que as "ondas rolam em espuma o embalo do [...] terror (p. 239); na plenitude da montanha, descobre o longínquo de "uma paz triunfal" (p. 130), a verdade da vida que só ali se cumpre para sempre, "na secreta imobilidade das coisas, na pureza lunar de uma neve nocturna” (p. 133); nas mãos de Cristina que erguem o mundo, quando sentada ao piano, surge, como uma revelação, "tudo quanto era verdadeiro e inextinguível" (p. 40); na escrita, parece ser possível criar a vida, reformá-la, pois escrever é tentar saciar o desejo de se esclarecer na posse do que se conta. É para ser que Alberto Soares escreve, para segurar nas suas "mãos inábeis o que fulgurou e morreu" (p. 193), para, ao realizar uma obra, "um mal-estar não ter razão"

Enredado na teia da existência, busca incessantemente o fio de Ariadne que o liberte e com ele vai entretecendo as malhas de um texto cujos elos se esfumam na névoa da memória, instaurando a descontinuidade no discurso:

Mas os elos de ligação entre os factos que narro é como se se diluíssem num fumo de neblina e ficassem só audíveis, como gritos, que todavia se respondem na unidade do que sou, os ecos angustiantes desses factos em si-padrões de uma viagem que já mal sei 5 .

Deambulando de fragmento em fragmento, embrenhando-se no labirinto da escrita, mais não faz do que tentar figurar o infinito, vencer o efémero, agarrar o instante da fulguração, sentir o eterno.

Face ao que acaba de ser enunciado, levantam-se duas questões complementares: cidade labiríntica e escrita descontínua não serão apenas o reflexo de uma vivência particular do tempo? Vontade de criação de um texto e necessidade de

3 Vergílio Ferreira, Pensar, Venda Nova, Bertrand Editora, 1998, 6a ed., p. 36. Lê-se no mesmo passo: "Escrevo para tornar possível a realidade, os lugares, tempos, pessoas que esperam que a minha escrita os desperte do seu modo confuso de serem. E para evocar e fixar o percurso que realizei, as terras, as gentes e tudo o que vivi e que só na escrita eu posso reconhecer, por nela recuperarem a sua essencialidade, a sua verdade emotiva, que é a primeira e a última que nos liga ao mundo". Mais à frente, o autor acrescenta: "Escreve-se para se saber o que se é" (p. 109).

4 Id., ibidem, p. 87: "Realiza-se uma obra para um mal-estar não ter razão".

5 Vergílio Ferreira, Aparição, Venda Nova, Bertrand Editora, 2000, 50ª ed., p. 24. 
construção de uma outra cidade, a Cidade do Homem, não serão apenas duas facetas de uma mesma realidade em que impera o anseio de libertação de limites espácio-temporais e a dimensão do eterno?

É a estas perguntas que se procurará dar resposta, a partir de uma reflexão sobre o romance de Vergílio Ferreira, a qual se centrará nas ideias de espaço e de escrita, de vida e de morte, de instante e de eternidade ${ }^{6}$, todas elas ligadas à noção de labirinto que, segundo Jean Chevalier e Alain Gheerbrant, "exprimerait une volonté très evidente de figurer l'infini [...]. La transformation du moi qui s'opère au centre du labyrinthe [...] marquera la victoire du spirituel sur le matériel et, en même temps, de l'éternel sur le périssable, de l'intelligence sur l'instinct, du savoir sur la violence aveugle" 7 .

A rede de ruas apertadas, com "cruzamentos enviesados" (p. 175) por onde o protagonista se perde, obriga à decifração de obscuras placas de trânsito, do mesmo modo que a interpenetração das sequências do romance exige a atenção e um esforço hermenêutico do leitor para desvendar os vetores que orientam a ação da obra. Paralelamente, "a vida imediata, quotidiana, é uma selva de caminhos, de veredas, de confusa vegetação" (p. 91) onde se torna fácil perdermo-nos, sem que disso tenhamos consciência. A escolha de um caminho pessoal que se impõe a cada instante pressupõe angústia, ao responsabilizar o indivíduo que não ignora que essa escolha envolve toda a humanidade ${ }^{8}$. As casas, que se "baralhavam numa intersecção de planos, como num jogo de axiomas estéreis" (p. 99), parecem ser um eco alarmante do passado ilegível, de uma vida de outrora assinalada por breves pontos de referência abertos "ao que ressoa como música de esferas", como uma vibração cósmica, para se rarefazer numa "névoa

\footnotetext{
6 Sobre as noções de 'instante' e de 'eterno', leia-se o que Jaspers escreve a esse propósito: "Passado e futuro são abismos escuros, informes, tempo indefinido, ao passo que o instante pode ser a abolição do tempo, a presença do eterno" (apud Nicola Abbagnano, Dicionário de Filosofia, S. Paulo, Martins Fontes, 1998).

7 Jean Chevalier e Alain Gheerbrant, Dictionnaire des Symboles, Paris, Laffont, 1982 (1 $1^{\text {a }}$ ed., 1969), p. 556.

8 Jean-Paul Sartre, O Existencialismo é um Humanismo, Lisboa, Editorial Presença, 1970, $3^{\text {a }}$ ed., p. 219: "Escolher ser isto ou aquilo é afirmar ao mesmo tempo o valor do que escolhemos, porque nunca podemos escolher o mal, o que escolhemos é sempre o bem, e nada pode ser bom para nós sem que o seja para todos". Por essa razão, "o' caminho que se impõe a cada instante que passa" (p. 91) a Alberto Soares leva-o a afirmar, no final de Aparição: "Aceito a responsabilidade de tudo, porque aceito a responsabilidade da minha vida" (p. 267).
} 
que os esbate como um murmúrio de nada" (p. 79). Daí a negar-se a existência do passado vai um curto passo:

O passado não existe. Assim me acontece às vezes que toda a minha vida de outrora se me revela ilegível: o que a forma não são factos, sentimentos que se analisam ou reconheçam, mas os ecos alarmantes de um labirinto onde a chuva, o sol repercutem e quase criam uma estranha vibração?.

Sendo difícil entender tudo o que pré-existe ao instante da revelação do ser, torna-se, pois, impossível recuperar o passado sempre tão opaco e frágil quanto as palavras-pedras. É na altura em que percorre em todos os sentidos o labirinto das ruas de uma zona da cidade em que segredos e suspeitas se entrecruzam, que Alberto Soares se dá conta que Carolino conhece já a "fragilidade das palavras" (p. 74); é quando reflete sobre Babilónia, em oposição a Jerusalém, cuja miragem apenas fugazmente nos visita de tempos a tempos, que lhe revela que nelas só vive "o espírito que por elas passa" (p. 120); é no momento em que a cidade se lhe afigura morta há séculos, em que vozes se repercutem pelas galerias como num labirinto, que o protagonista é invadido pelo sentimento de que talvez tenha ainda algum poema para escrever e pela necessidade de "se visitar de vez em quando” (p. 113), de se não perder da sua aparição.

Escrever um poema (de $\pi$ olé $\omega$, fazer, criar), realizar uma obra, unir os fragmentos expostos numa "pobre feira da ladra - a vida" (p. 92), ordenar os destroços da alucinação capazes de dizer "espalhadamente" (p. 97) o que se pretende exprimir são as únicas formas possíveis de descobrir a verdade primitiva de si próprio, desse "elo perdido entre a infinidade de elos" (p. 50). É escrevendo que se busca na noite a fulguração do ser para a morte, que se procura a solução para o problema essencial: "justificar a vida em face da inverosimilhança da morte (p. 49). Contudo, cristalizar os instantes de aparição, sem os banalizar, obriga a uma luta com as palavras e consigo mesmo. Só assim será possível achar a tão procurada evidência para nela estabelecer a vida em plenitude ${ }^{10}$. Fixar os pontos essenciais das suas ideias é o grande objetivo que desencadeia toda a história

\footnotetext{
9 Vergílio Ferreira, Aparição, Venda Nova, Bertrand Editora, 2000, 50ª ed., p. 79.

$10 \quad$ Id., ibidem, p. 102: "Quero achar a evidência que procuro, estabelecer nela a minha vida em plenitude".
} 
narrada por Alberto Soares que continuamente se confronta com a opacidade e o mistério das palavras:

E todavia como é difícil explicar-me! Há no homem o dom perverso da banalização. Estamos condenados a pensar com palavras, a sentir em palavras, se queremos pelo menos que os outros sintam connosco. Mas as palavras são pedras. Toda a manhã lutei não apenas com elas mas comigo mesmo para apanhar a minha evidência ${ }^{11}$.

A esta, outra dificuldade se vem juntar: é que "toda a nossa vida é feita de farrapos, de bocados", de fragmentos de uma unidade desconhecida e "somos incapazes de unificar o nosso tempo"12. Por essa razão, a progressão cronológica que carateriza o romance tradicional, cuja intriga pressupõe a existência de relações causais-temporais muito fortes, não pode senão ser postergada para dar lugar a uma construção baseada na subversão do tempo, a nível do discurso, fazendo lembrar a arte da fuga de certas composições musicais. Se se privilegia o instante da pura aparição, anterior a qualquer determinação, se o homem é o que ele faz, então, o determinismo próprio dos romances naturalistas não tem razão de ser, como prova Sartre em O Existencialismo é um Humanismo ${ }^{13}$. Na obra de Vergílio Ferreira, em particular em Aparição, "há uma vivência muito própria do tempo em que os contrários se encontram e se unem, para daí resultar um discurso complexo"14.

11 Id., ibidem, p. 44. Nesta mesma página, lê-se igualmente: "Um dia poderia desenvolver as minhas ideias num estudo mais longo; agora precisava de as fixar nos pontos capitais. E foi isso que desencadeou toda a história que narro".

12 Vergílio Ferreira, Pensar, Venda Nova, Bertrand Editora, 1998, 6a ed., pp. 123 e 259.

13 Vd. Jean-Paul Sartre, O Existencialismo é um Humanismo, Lisboa, Editorial Presença, 1970, $3^{a}$ ed., pp. 244-245: "Se há pessoas que nos censuram as nossas obras nas quais apresentamos seres indolentes, fracos, cobardes e algumas vezes francamente maus, não é unicamente porque estes seres são indolentes, fracos, cobardes ou maus; porque se, como Zola, disséssemos que eles são assim por causa da hereditariedade, tais pessoas ficariam sossegadas e diriam: ora aí está, somos assim, contra isso ninguém pode nada. Mas o existencialismo, quando descreve um cobarde, diz que este cobarde é responsável pela sua cobardia. [...] o cobarde é definido a partir do acto que praticou".

14 Maria Joaquina Nobre Júlio, Subsídios para uma Leitura de "Aparição", de Vergílio Ferreira,

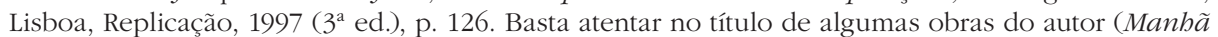
Submersa, Apelo da Noite, Alegria Breve, Para Sempre, Até ao Fim, Arte Tempo, Carta ao Futuro...), para se concluir que o tempo é uma das suas preocupações centrais. 
Tal facto, porém, não é incompatível com a vontade de impor uma ordem estruturada no que poderia parecer o caos. Caso contrário, como compreender o sentido dos seguintes passos:

Havia a minha dedicação pela velha tia Dulce e pelo seu velho álbum, de que depois falare ${ }^{15}$;

A minha história espera-me mais terrivel do que nunca, disparando para o seu desfecho ${ }^{16}$;

Para que insistir na minha inquietação e na sua narrativa como quem quer retardar um efeito teatral ${ }^{17}$ ?

De facto, a reflexão prévia sobre o desfecho da narrativa no corpo do próprio texto e os constantes avanços e recuos na ação pressupõem não só a subversão do tempo linear e a tomada de consciência de diversas técnicas romanescas, como ainda uma evidente ideia de unidade do romance ${ }^{18}$, cuja construção vai sendo desvendada aos olhos do leitor, cúmplice de um narrador que se assume como escritor. O leitor pode, assim, partilhar, de alguma forma, com o autor, a tarefa da criação, o ato da escrita.

Ora, precisamente a escrita parece ser a única saída de um espaço labiríntico cercado por muros sem portas, semelhante à morte ("a morte é um muro sem portas", p. 110), que aprisiona o homem; é a única fuga possível ao tempo transformado em espaço, tempo que "é a forma humana de ser, a condição que em nós tudo condiciona"19. Todavia, se, como afirma Jacques Attali, "[l'homme labyrinthique] ne débouche en fait que sur un chemin menant à un autre labyrinthe" ${ }^{20}$, não é de estranhar que o texto produzido se assemelhe a um

15 Vergílio Ferreira, Aparição, Venda Nova, Bertrand Editora, 2000, 50a ed., p. 25.

16 Id., ibidem, p. 157

${ }^{17}$ Id., ibidem, p. 266.

18 Armine Kotin Mortimer, La Clôture Narrative, Paris, José Corti, 1985, p. 26: “...l'image la plus immédiate qui s'attache à la notion de clôture narrative, après celle de la fermeture, est certes celle de l'unité, qui dépend de la création d'un monde clos possédant de l'ordre et de la cohérence et fonctionnant comme un tout organique".

19 Vergílio Ferreira, Invocação ao meu Corpo, Venda Nova, Bertrand Editora, 1969, p. 86.

20 Jacques Attali, Chemins de la Sagesse. Traité du Labyrinthe, Paris, Fayard, 1996,p. 210. 
dédalo, até porque, "en art, se perdre est la condition de la création" ${ }^{21}$. A escrita, como a arte em geral, permite a descoberta da eternidade, mesmo que esta dure muito pouco e que a conheçamos apenas na intensidade de um instante ${ }^{22}$. Ela é "a base última de um verdadeiro humanismo", pois tem por fim "instalar o homem nos aposentos divinos" (p. 110). Ao criar o labirinto da escrita, Vergílio Ferreira põe a descoberto o limite da vida, ao mesmo tempo que se consubstancia com ele, pois sabe que "a própria imagem da amargura, revelada na arte, é [...] um anúncio de plenitude"23; expõe a angústia humana, ao mesmo tempo que transforma "o finito em quase-infinito" 24 ; enfrenta corajosamente e assume a miséria da humilhante condição humana, ao mesmo tempo que se aproxima da máxima espinosiana segundo a qual "nós sentimos e experimentamos que somos eternos" 25 , ao afirmar:

A eternidade mora em nós e na vida, deixa apenas que ela se diga e te habite. E serás mais do que Deus, cuja eternidade passou ${ }^{26}$.

${ }^{21}$ Id., ibidem, p. 166.

22 Cf. Vergílio Ferreira, Introdução a O Homem em Processo. Malraux, Sartre, Camus, Saint-Exupéry, de Pierre-Henri Simon, Lisboa, 1967, p. 14: "Porque a eternidade dura muito pouco. Conhecemo-la apenas na intensidade de um instante". Em Arte Tempo, escreve também: "De qualquer modo a intemporalidade é em nós uma voz obsessiva e que deve ter por isso uma razão de ser. Como a paixão amorosa que é sempre eterna mesmo no seu efémero" (Vergílio Ferreira, Arte Tempo, s/l, Rolim, s/d, p. 37).

23 Vergílio Ferreira, Carta ao Futuro, Venda Nova, Bertrand Editora, 1985, 4ª ed., p. 82.

24 Jacques Attali, op. cit., p. 215: "Qui fabrique des labyrinthes transforme du fini en quasi-fini, empile du temps dans un espace limité comme l'homme empile du temps dans ses objets".

25 Bento Espinosa, Ética Demonstrada à Maneira dos Geómetras, Livro III, Coimbra, Atlântida, 1965, p. 127: "Como dissemos, essa ideia exprime a essência do Corpo, do ponto de vista da eternidade, é um certo modo de pensar, que pertence à essência da Alma e que é necessariamente eterno. E, no entanto, não pode suceder que nos recordemos de ter existido antes do Corpo, visto que não pode haver no Corpo nenhuns vestígios disso, nem a eternidade pode ser definida pelo tempo, nem pode ter nenhuma relação com o tempo. Mas, não obstante, nós sentimos e experimentamos que somos eternos" (Parte V, "Da Potência da Inteligência ou da Liberdade Humana", Proposição XXIII, Escólio).

26 Vergílio Ferreira, Pensar, Venda Nova, Bertrand Editora, 1998, 6a ed., p. 124: "Não tenhas medo de ser mortal e de não mereceres a eternidade. Porque a eternidade está em ti, no momento incrível de te desprenderes do teu corpo, da tua miséria e estrume, e te pensares a ti mesmo e te sentires ser. Ou quando uma imagem de outrora, luminosa, ténue, se abre ao teu imaginar. Ou quando, fulminante, uma obra de arte. Ou quando, violento intenso instantâneo, o todo de uma mulher. Ou quando pela manhã a terra espera em silêncio que o dia vá começar. A eternidade mora em nós e na vida, deixa apenas que ela se diga e te habite. E serás mais do que Deus, cuja eternidade passou". 
Ao partir de Évora, Alberto Soares leva nos olhos, para a vida inteira, a imagem pictórica das ruínas, da solidão da planície e do silêncio. A visão da cidade em chamas, "aberta de quarteirões, de praças, de sonhos" (pp. 268-269), opõe-se ao universo fechado, por muralhas e pela mesquinhez das mentalidades, do meio pequeno que conhecera. Um tal cenário de destruição parece sugerir a suspensão do tempo, como acontece, por exemplo, nos quadros de ruínas de Hubert Robert que põem em cena "la confrontation de temps et d'éternité, d'espace et d'infini (ce que postule aussi le fragment)"27.

Ao escapar ao desastre, Alberto Soares sente-se só e nu, purificado pelo fogo e pela água da lua que lhe banha o "corpo perecível" (p. 272). Trespassado pelo "fluido da eternidade", declara:

O tempo não passa por mim: é de mim que ele parte, sou eu sendo, vibrando ${ }^{28}$.

Num curioso sincretismo temporal, o passado reflete-se nas sensações e sonhos do presente e o futuro não é mais do que o que agora se projeta. A Cidade do Homem, que pretende fundar noutro lado, habita o seu sonho, dura no seu interior como a música que ajudará a erigi-la. Os compassos de Bach, Beethoven, Mozart, Chopin, que as mãos de Cristina fazem vibrar, são a lira de Orfeu e de Anfíon, capazes de mover as pedras de um novo reino. Não é, aliás, por certo fortuita a alusão aos mitos do poeta, Orfeu, e do músico, Anfíon, um dos responsáveis pela construção da muralha de Tebas, cidade da esfinge, detentora do mistério das palavras, cujos enigmas se centram, precisamente, nas noções de 'homem' e de 'tempo'.

A Cidade do Homem será, pois, a cidade da arte onde "a vida do homem é cada instante - eternidade onde tudo se reabsorve, que não cresce nem envelhece -, centro de irradiação para o sem-fim de outrora e de amanhã” (p. 273). Só a obra de arte poderá satisfazer o anseio de eternidade, pois só ela "tem um núcleo de questões a que se vão dando respostas através dos tempos"29. Se, ao fim do texto, o narrador-autor encontra o apaziguamento, é porque parece ter dominado o tempo, ao escrever a obra, o mesmo é dizer, ao construir o seu

27 Pierre Garrigues, Poétiques du Fragment, Paris, Klincksieck, 1995, p. 35.

28 Vergílio Ferreira, Aparição, Venda Nova, Bertrand Editora, 2000, 50ª ed., p. 273.

29 Vergílio Ferreira, Pensar, Venda Nova, Bertrand Editora, 1998, 6 a ed., p. 257. 
reino, a cidade do homem e da arte, da música e da comunhão, onde "a morte não deve ter razão contra a vida nem os deuses [...] contra os homens"30.

O epílogo que retoma o início do romance ("Sento-me aqui nesta sala vazia e relembro", pp. 9 e 272) parece desenhar um círculo que encerra o dédalo do texto, mas as reticências finais, que o deixam em aberto, permitem antes traçar uma espiral que se liga à simbologia cósmica da lua, da renovação, do tempo que passa, do labirinto ${ }^{31}$, e que representa "la permanence de l'être sur la fugacité du moment"32. A arte pode terminar "na forma, mas é na emoção que começa"33.

Em suma, círculo e espiral poderão representar o que talvez se possa designar por conatus $^{34}$ da narração ou da arte, isto é, a tensão entre a obra acabada e a sua natureza essencialmente criadora, entre limites temporais e eternidade. Essas duas figuras são a linha ou o fio de Ariadne com que se tece o discurso ${ }^{35}$ libertador das garras do tempo, porque só com ele se pode prender o instante fulgurante e intransmissível da aparição ${ }^{36}$.

30 Vergílio Ferreira, Aparição, Venda Nova, Bertrand Editora, 2000, 50ª ed., pp. 269-270. A esta visão da Cidade do Homem se opõe, por exemplo, a Cidade do Sol, em que são necessários sacrifícios humanos, preces e jejuns, para purificar a urbe, para que seja "aplacada a cólera divina" (Tomás Campanella, A Cidade do Sol, Lisboa, Guimarães \& C C $^{\mathrm{a}}$ Editores, s/d, p. 72).

31 Jean Chevalier e Alain Gheerbrant, Dictionnaire des Symboles, Paris, Laffont, 1982 ( $1^{\mathrm{a}}$ ed., 1969), p. 556: "Le labyrinthe serait une combinaison de deux motifs de la spirale et de la tresse et exprimerait une volonté très évidente de figurer l'infini [...] perpétuellement en devenir de la spirale, laquelle, théoriquement du moins, peut être pensée sans achèvement, et l'infini de l'éternel retour figuré par la tresse".

32 Id., ibidem, p. 907.

33 Vergílio Ferreira, Arte Tempo, s/1, Rolim, s/d, p. 28.

34 Pierre Campion, La Littérature à la Recherche de la Vérité, Paris, Seuil, 1996, p. 31: "Pour Spinoza, "chaque chose, selon sa puissance d'être, s'efforce de persévérer dans son être" et il appelle conatus cette tension perpétuelle de la substance et sa nature essentiellement productive. Dans cette perspective, nous aimerions proposer maintenant l'idée de conatus de la narration. [...] En somme, le fil qui ne s'interrompt jamais, l'unité que l'on cherche souvent [...] du côté des structures du récit, cette unité se discernerait plutôt dans la continuité de la narration, entendue comme le développement du conatus d'un sujet exclusivement défini dans et par ce processus même". Cf. Espinosa, Ética Demonstrada à maneira dos Geómetras, Livro II, Coimbra, Atlântida, 1962, p. 100: "O esforço pelo qual cada coisa tende a perseverar no seu ser não envolve tempo finito, mas um tempo indefinido" (Parte III, "Da Origem e da Natureza das Afecções", Proposição VIII). Para Vico, conatus "é a natureza [...] in fieri, prestes a chegar à existência" (apud Nicola Abbagnano, Dicionário de Filosofia, S. Paulo, Martins Fontes, 1998).

35 Gaston Bachelard, La Terre et les Rêveries du Repos. Essai sur les Images de l'Intimité, Paris, José Corti, 1948, p. 215: "Ainsi, si l'on se permet de jouer sur les mots, on peut dire que le fil d'Ariane est le fil du discours".

36 Revela-se absurda e vã a tentativa de transmitir a outrem a revelação da "pessoa" humana, levada a cabo pelo protagonista de Estrela Polar, romance que também termina em reticências e que, como afirma o autor, "continua, de alguma forma, Aparição" (Vergílio Ferreira, Estrela Polar, Lisboa, Portugália, s/d, p. 6). 